DOI:

Дмитро Павленко, аспірант кафедри освіти дорослих Національного педагогічного університету імені М.П. Драгоманова

\title{
ДО ПИТАННЯ ПРОФЕСІЙНОЇ ПІДГОТОВКИ МАЙБУТНІХ ФАХІВЦІВ 3 ПУБЛІЧНОГО УПРАВЛІННЯ У ПЕДАГОГІЧНИХ ЗАКЛАДАХ ВИЩОЇ ОСВІТИ
}

Здійснено методологічне обтрунтування розроблення моделі організації освітнього процесу професійної підготовки майбутніх фахівців з публічного управління зі встановленням відповідності імплементації освітньо-наукових систем закладів вищяої освіти Украӥни міжнародним інституційним об 'єднанням з публічного управління шляхом очінювання рівня сформованості їх професійної компетентності (низький, середній, достатній та високий) на основі розроблених критерїв (когнітивно-функиіональний, раціонально-менеджерський, ноосферно-квалітологічний) до початку та після проведення експерименту.

Ключові слова: професійна підготовка; майбутні фахівиі; публічне управління; заклади вищої освіти. Jim. 9.

Dmytro Pavlenko, Postgraduate Student of the Adult Education Department, National Mykhaylo Drahomanov Pedagogical University

\section{TO THE QUESTION OF PROFESSIONAL TRAINING OF FUTURE SPECIALISTS OF PUBLIC MANAGEMENT IN PEDAGOGICAL INSTITUTIONS OF HIGHER EDUCATION}

The article deals with the methodological substantiation of development of model of organization of educational process of professional training of future specialists in public management in the field of knowledge 28 "Public administration and administration" with establishment of conformity of implementation of educational and scientific systems of higher education institutions of Ukraine to international institutional association on public management by estimating their professional level; competence (low, medium, sufficient and high) on the basis of the developed criteria (cognitive-functional, rational-managerial, noosphere-qualitological) before and after the experiment. The study was performed within the consolidated plan of research in the field of education, science and innovation "Theoretical and methodological foundations of postgraduate education on the basis of sustainable development", "Substantiation of methodological and practical principles of development and implementation of environmental management of higher education" and the Main Intelligence Department of the Ministry of Defense of Ukraine within the GDR "Formation, preparation and implementation of the intelligence reserve in modern conditions", code "Hoverla". Methodological basis of recommended and tested content-educational modules "Methodology - research, systems management, administrative training, evaluation and examination", "Policyquality management, education, sustainable development strategy, socio-economic and environmental security", public, state, municipal, administrative, local self-government, development (socio-economic, environmental, institutional, security)" and "Professional pedagogy and special psychology of public administration", the effectiveness of which is confirmed by expert evaluation.

Keywords: professional training; future specialists; public administration; institutions of higher education.

П остановка проблеми. Соціальне замовлення на професійну підготовку майбутніх фахівців з публічного управління галузі знань 28 “Публічне управління та адміністрування" дає підстави для актуалізації педагогічного дослідження у виокремлених суперечностях між : соціально-економічним замовленням на фахівців з публічного управління та академічним потенціалом наукових шкіл закладів вищої освіти (далі - ЗВО) щодо методології формування їх професійної компетентності для сфер працевлаштування та професійних середовищ зайнятості; суспільними потребами гармонізації системоутворюючого адміністративного впливу на об'єкти управління в сфері освіти, науки й інноватики та рівнем якості професійної підготовки майбутніх фахівців 3 публічного управління у інституційній організації ЗВО; необхідністю управління доступом до суспільно-важливої інформації здобуття освіти та професійного розвитку за традиційними формами соціо-культурної організації професійної підготовки майбутніх фахівців з публічного управління [9]. Дослідження виконано в межах зведеного плану науково-дослідних робіт у сфері освіти, науки та інноватики “Теоретичні та методичні основи формування системи післядипломної освіти на засадах сталого розвитку” (ДР № 0117U004914), "Обгрунтування методичних та практичних засад розробки і впровадження системи екологічного управління вищими навчальними закладами" (ДР № 0115U003405) та Головного управління 


\section{ДО ПИТАННЯ ПРОФЕСІЙНОЇ ПІДГОТОВКИ МАЙБУТНІХ ФАХІВЦІВ 3 ПУБЛІЧНОГО УПРАВЛІННЯ У ПЕДАГОГІЧНИХ ЗАКЛАДАХ ВИЩОЇ ОСВІТИ}

розвідки Міністерства оборони України в межах НДР “Формування, підготовка та виконання резерву агентурної розвідки в сучасних умовах" (ДР № 0118U000020), шифр “Говерла”.

Аналіз основних досліджень і публікацій. Методологічну основу педагогічного дослідження складають філософсько-фундаментальні аспекти управління в сфері освіти, науки й інноватики праці В. Андрущенка, В. Бондаря, Б. Гершунського, C. Пазиніча, О. Пономарьова, R. Barrow; стратегічні засади освітньої політики та управління її якістю досліджували I. Іванюк, А. Ярошенко, Т. Brackston, D. Goldblatt, P. Lodge, J. Perraton та ін. Глобальної метрики освіти спостерігали 3. Бауман, В. Бебик, О. Білорус, І. Валлерстайн, Д. Гелд, С. Гессен, К. Корсак, О. Огієнко, Г. Томпсон, Є. Тюфлер, M. Kwiek, S. Marginson, R. Robertson; суспільні орієнтири як засоби соціо-культурних форм впливу на цивілізаційний розвиток аналізували E. Durkheim, D. Martin, L. Sklair; педагогічну інноватику педагогічного дослідництва досліджували Н. Бабіна, Л. Буркова, В. Ващенко, В. Вербицький, Н. Дем'яненко, Н. Рідей $[7 ; 5 ; 6]$; прогностичні підходи розвитку вищої освіти вивчали Н. Newby, F. Newman, A. Toffler, A. Combs; формування академічного потенціалу якості сформованості компетенцій розглядали С. Калашнікова, В. Ковтунець, С. Курбатов, В. Луговий, Т. Маматова, Г. Михайлишин, В. Огвоздін, Н. Рідей, Ж. Таланова, О. Чувпило; наукові праці В. Боголюбова, П. Гусака, М. Корця, Т. Саєнко, Л. Сущенко, С. Яшник, W. Furmanek, W. Sobczyk, W. Walat охоплюють питання пов'язані зі сферою адміністративного управління вищої школи та професійного розвитку.

Мета статті полягає в методологічному обгрунтуванні розробки моделі організації освітнього процесу професійної підготовки майбутніх фахівців з публічного управління. Завдання дослідження: встановити відповідність імплементації міжнародним інституційним об'єднанням з публічного управління; розробити та науково обгрунтувати модель організації професійної підготовки майбутніх фахівців 3 публічного управління.

Виклад основного матеріалу. Формування професійної компетентності майбутніх фахівців 3 публічного управління у ЗВО узгоджено у співпраці Фонду відновлення та стійкості (з англ. - Recovery and Resilience Facility, далі - Facility) підтримки реформ та інвестицій можливостей екологічної та цифрової політики розвитку щодо пом'якшення соціо-економічного впливу пандемії на безпеку й якість життя; Європейського інституту публічного адміністрування (з англ. -
European Institute of Public Administration, далі EIPA) зі наданням практичних компетентностей ефективного управління та політики, компаративістики 3 аналітикою перспектив розвитку для розбудови національних мереж (у програмах Using REACTEU and the RRF while Implementing the New Structural Funds Programmes, 2021-2027); Європейського визнання громадського сектора (з англ. - European public sector award, далі - EPSA) як платформи для досягнення суспільних переваг європейською мережею досконалості державного сектору; Свропейської мережі публічного адміністрування (з англ. - European Public Administration Network, далі - EUPAN) неформальної спілки генеральних дирекцій, відповідальних за публічне управління зі Стратегією (з англ. - EUPAN Strategy Paper 2019-2022) пошуку ефективних способів відбору пріоритетних тем для спільного порядку денного у XXI ст., яка сприяє розробці загальних інструментів, заходів та консенсусу; Свропейських магістерських студій (з англ. - Master of European Legal Studies (MELS online) 2021-2023) у партнерстві $з$ консорціумами та експертами в академічному та професійному середовищі організації та пропагування магістерських програм 3 управління й адміністрування Свропейського центру університетів (CEU).

Педагогічне дослідження спрямовано на досягнення мети стратегічного значення забезпечення якості життя усіх учасників освітнього процесу та зацікавлених сторін при гармонізації соціально-політичної взаємодії систем управління соціо-культурними формами підготовки та розвитку на засадах сталості, а також иільового призначення щзодо формування професійної компетентності у майбутніх фахівців 3 публічного управління $[1 ; 2 ; 4 ; 8]$ на теоретичних і методичних засадах методології системного управління (пізнання, навчання, оцінювання); впровадження методики організації освітнього процесу професійної підготовки у 3ВО у стратегічно-иільовій підсистемі, яка базується на парадигмальних підходах - ноосферологічний, квалітологічний, нового публічного менеджменту, до прийняття управлінських рішень, наукових, публічного управління та підходах організації освітнього процесу-інноваційний, синергетичний, навчально-, науково-, пізнавально-діяльнісний, менеджеризму, компетентнісний, аналітикодіагностичний керівного впливу, особистісноорієнтований студентоцентричний; тріади принципів - загальних (публічного управління, державного управління, структурних, “Чандлера", організації виконавчої влади), спеціальних 


\section{ДО ПИТАННЯ ПРОФЕСІЙНОӤ ПІДГОТОВКИ МАЙБУТНІХ ФАХІВЦІВ 3 ПУБЛІЧНОГО УПРАВЛІННЯ У ПЕДАГОГІЧНИХЗАКЛАДАХ ВИЩОЇ ОСВІТИ}

(прийняття управлінських рішень, раціональної структури управління, універсальності управління) та функціональних організації освітнього процесу (неперервності освіти впродовж життя, систематичності та відповідності науковій теорії, послідовності внутрішньо- і міжпредметного зв'язку, прогностичності компетентності зорієнтованої на професійну діяльність та інноваційність, доступності, зв'язку з життям, єдності науки, навчання і практики, андрагогічності, елективності, портативності). Стратегічно-цільова підсистема професійної підготовки майбутніх фахівців з публічного управління покликана реалізувати місію задоволення потреб соціального замовлення (соціо-економічне, еколого-безпечне якості та сталого розвитку) на фахівців 3 публічного управління в управлінській архітектоніці організації систем на рівнях, у типах за службовим призначенням для структурноорганізаційних підрозділів публічного (державного, муніципального), цивільного управління : звернення громадян, зв'язків 3 громадськістю, інформаційно-комунікаційної взаємодії, моніторингово-аналітичних, громадського нагляду та контролю, просвітницьких, консалтингово-дорадчих зі надання послуг та сервісів.

У ході педагогічного експерименту перевірено припущення, що формування професійної компетентності у майбутніх фахівців з публічного управління у ЗВО нарощується за рахунок розроблення методики організації освітнього процесу з науково-методичним забезпеченням та впровадженням однойменної моделі в управлінсько-педагогічних умовах функціональної реалізації для досягнення релевантності, достовірності та доведеності даних дослідження. Синергетичну взаємодію підсистем професійної підготовки забезпечено емерджетною цілісністю методично-організаційної та функиіональнозмістової підсистем реалізації [3] навчальнонауково-пізнавальна, адміністративно-інституційна, практично-стажувальна діяльності у формах організації освітнього процесу за комплектацією, дислокацією та дидактичною метою (змішана, мережева, дистанційна, мобільна, традиційна) методологічного базису рекомендованих та апробованих змістовно-освітніх модулів “Методологія - наукових досліджень, системного управління, навчання адміністративного управління, оцінювання та експертизи”, “Політика - управління якістю, освітня, стратегія сталого розвитку, соціально-економічна та екологічної безпеки”, “Управління - публічне, державне, муніципальне, адміністративне, місцевого самоврядування, розвитком (соціальноекономічним, екологічним, інституційним, безпеки)" та “Професійна педагогіка та спеціальна психологія публічного управління та адміністрування", ефективність яких підтверджена експертним оцінюванням. Модель організації професійної підготовки майбутніх фахівців 3 публічного управління до педагогічної діяльності активізується в амплітуді функціонального призначення майбутньої професійної зайнятості. Апробація моделі розрахована на активацію функцій дуальної реалізації професійної підготовки згідно особливостей: публічного управління регулююча (з розробки та реалізації політичних програм), примусу (демократичного порядку), забезпечувальна (правового захисту), організаційна (правові і соціальні служби), адміністративна культура економічних гарантій, правотворча, контролю; загальні-інформаційна, прогнозування i моделювання, планування організації, встановлення компетенції суб'єктів управління, керуюча, координуюча, регулятивна; спещифічні - соціально-економічної розбудови, кадрової політики, визначення кваліфікаційних вимог до фахівців, унормування профкваліфікаційних характеристик, оргметодичне керівництво профпідготовкою та розвитком, інформаційноаналітична, наглядова (суспільної безпеки, захисту життя, природи, здоров'я і власності), наукоємкої конверсіі; управлінські за видами діяльності основні (прогнозування та планування, організації, координації та регулювання, мотивації та контролю), допоміжні (за специфікою та етапами процесу управління, політико-адміністративні, соціо-економічні, культурно-освітні). Методика організації освітнього процесу професійної підготовки грунтується на системному комплексі методів : аксіологічної вмотивованості, науковометричні (інтерактивні, проблемно-ситуаційні), за джерелом інформації академічної спадщини, рівнем креативності, за логікою пізнання (самопізнання), нагляду, моніторингу та самоконтролю, поліоб'єктні зі застосуванням сучасних засобів навчально-науково-пізнавальної, конслатинго-дорадчої та практично-стажувальної діяльності : просторово-метричні (графічнодемонстраційні, інформаційні), технологічні (вебмоделювання, IКТ, мультимедійні, дистанційні, геостатистичні), лабораторно-технічні (інформаційноаналітичні, моніторингові, АCК, просвітницькі-PR, інтент-, контент-, івент-діагностики), методологічні та техніко-регулятивні (науково-методичні, метрологічні, стандартизації); форми навчальнонауково-пізнавальної, адміністративно-інституційної, практично-стажувальної діяльності в організації 


\section{ДОПИТАННЯ ПРОФЕСІЙНОӤ ПІДГОТОВКИ МАЙБУТНІХ ФАХІВЦІВ 3 ПУБЛІЧНОГО УПРАВЛІННЯ У ПЕДАГОГІЧНИХЗАКЛАДАХ ВИЩОЇ ОСВІТИ}

освітнього процесу за комплектацією, дислокацією та дидактичною метою - змішана, мережева, дистанційна, мобільна, традиційна; результативна niдсистема перевірено узапропонованих критеріях - когнітивно-функціональний, раціональноменеджерський, ноосферно-квалітологічний та рівнях - низький, середній, достатній, високий, де результатом є сформованість професійної компетентності майбутніх фахівців з публічного управління в заданих управлінсько-педагогічних умовах (освітня політика якості і безпеки життя; неперервна професійна самоосвіта та розвиток, самоменеджмент; академічна мобільність та професійна зайнятість).

Висновки і перспективи подальших досліджень. Педагогічне дослідження здійснено у етапах - професійно-орієнтований (лідерськоідентифікаційний), селективний (скринінговий), констатувальний, адміністративно-формувальний, релевантний, де основною метою експерименту було визначено ефективність застосування розробленої моделі у освітньому процесі підготовки майбутніх фахівців з публічного управління шляхом оцінювання рівня сформованості їх професійної компетентності (низький, середній, достатній та високий) на основі розроблених критеріїв (когнітивно-функціональний, раціонально-менеджерський, ноосферноквалітологічний) до початку та після проведення експерименту. Досягнуто цілі дослідження аксіології понятійно-наукового апарату професійної підготовки майбутніх фахівців 3 публічного управління; розроблено та науково обгрунтовано модель організації професійної підготовки майбутніх фахівців з публічного управління.

\section{ЛIТЕРАТУРА}

1. Воронько О.А. Керівні кадри: державна політика та система управління: навчальний посібник для студентів, слухачів із спец. "Держ. Управління”, “Держ. Управління”, “Держ. Служба”; Українська Академія держ. управління при Президентові України. 2000. Київ: Вид-во УАДУ.152 с.

2. Гончарук Н.Т. Керівний персонал у сфері державної служби України: формування та розвиток: монографія. Національна академія державного управління при Президентові України, Дніпропетр. регіон. ін-т держ. упр. 2007. Дніпропетровськ: ДРІДУ НАДУ. 238 с.

3. Рідей Н.М., Богуцький Ю.П., Шолудяк Н.М. Аналіз функцій управління в системі вищої освіти: аксіологічний і порівняльний аспекти. Нова педагогічна думка. 2015. №4. С. 13-23.

4. ASQ Z1.11-2002 - "Quality assurance standards - Guidelines for the application of ANSI" / ISO / ASQ Q9001-2000 to education and training institutions - AMERICAN SOCIETY FOR QUALITY, P.O. BOX 3005, WISCONSIN, 2000.

5. Bakhmat N., Liubarets V., Bilynska M., Ridei N., Anhelina S. Digital transformation of preparation of the future. Specialists in the economic industry in conditions of dual professional education. Selected Paper of 9th Cyprus International Conference on Educational Research (CYICER-2020). Vol. 7 No.3

6. Bakhmat N., Ridei N., Liubarets V., Ivashchenko V., Petrovska O., Averina K. Evaluation of the peculiarities of the implementation of the impulse stimulus of students in the process of educational activity. Systematic Reviews in Pharmacy. 2020. Vol. 11, Issue 11.pp. 1037-1041.

7. Dragan I.O., Kovalova O., Gryshchenko I., Ridei N., Livinskyi A. Assessment of dragan the role of the state as a leader in the demographic development of Ukraine. Solid State Technology, 2020. Vol. 63. No.6

8. ISO/IWA 2 "Quality management systems. Guidelines for the application of ISO 9001:2000 in education". Мексика: International Workshop Agreement, 2007.

9. Ridei N., Pavlenko D., Plakhotnik O., Gorokhova T., Popova A. Concept of forming the company innovation strategy. Academy of Strategic Management Journal. 2019. 18 (Special issue 1), pp. 1-6.

\section{REFERENCES}

1. Voronko, O.A. (2000). Kerivni kadry: derzhavna polityka ta systema upravlinnia: navchalnyi posibnyk dlia studentiv, slukhachiv iz spets. "Derzh. Upravlinnia", "Derzh. Upravlinnia”, "Derzh. Sluzhba”; Ukrainska Akademiia derzh. upravlinnia pry Prezydentovi Ukrainy [Management: the public policy and management system: a textbook for students, students of special. "The state. Management", State Management", "State Service"; Ukrainian Academy of State Department under the President of Ukraine]. Kyiv, 152 p.[in Ukrainian].

2. Honcharuk, N.T. (2007). Kerivnyi personal u sferi derzhavnoi sluzhby Ukrainy: formuvannia ta rozvytok: monohrafiia [The management staff in the field of civil service of Ukraine: formation and development: a monograph]. National Academy of Public Administration under the President of Ukraine, Dnipropetrovsk. region. Inst. manag. 238 p. [in Ukrainian].

3. Ridei, N.M., Bohutskyi, Yu.P. \& Sholudiak, N.M. (2015). Analiz funktsii upravlinnia v systemi vyshchoi osvity: aksiolohichnyi i porivnialnyi aspekty [An analysis of management functions in the higher 


\section{ІННОВАТИКА ФОРМУВАННЯ СТРАТЕГІЇ БЕЗПЕКИ В КОНТЕКСТІ ПРОФЕСІЙНОӤ ПІДОТОВКИ}

education system: an axiological and comparative aspects]. New pedagogical thought. No.4. pp. 1323. [in Ukrainian].

4. ASQ Z1.11-2002 - "Quality assurance standards - Guidelines for the application of ANSI" / ISO / ASQ Q9001-2000 to education and training institutions - AMERICAN SOCIETY FOR QUALITY, P.O. BOX 3005, WISCONSIN, 2000. [in English].

5. Bakhmat, N., Liubarets, V., Bilynska, M., Ridei, N. \& Anhelina, S. (2020). Digital transformation of preparation of the future. Specialists in the economic industry in conditions of dual professional education. Selected Paper of 9th Cyprus International Conference on Educational Research (CYICER2020). Vol. 7 No.3 [in English].

6. Bakhmat, N., Ridei, N., Liubarets, V., Ivashchenko, V., Petrovska, O. \& Averina, K. (2020).
Evaluation of the peculiarities of the implementation of the impulse stimulus of students in the process of educational activity. Systematic Reviews in Pharmacy. Vol. 11, issue 11.pp. 1037-1041. [in English].

7. Dragan, I.O., Kovalova, O., Gryshchenko, I., Ridei, N. \& Livinskyi, A. (2020). Assessment of dragan the role of the state as a leader in the demographic development of Ukraine. Solid State Technology, Vol. 63. No.6 [in English].

8. ISO/IWA 2 "Quality management systems. Guidelines for the application of ISO 9001:2000 in education". Meksyka: International Workshop Agreement, 2007. [in English].

9. Ridei, N., Pavlenko, D., Plakhotnik, O., Gorokhova, T. \& Popova, A. (2019). Concept of forming the company innovation strategy. Academy of Strategic Management Journal. 18 (Special issue 1), pp. 1-6. [in English].

Стаття надійшла до редакції 03.11.2020

УДК 378:005.51:351

DOI:

Олександр Слабецький, аспірант кафедри освіти дорослих Національного педагогічного університету імені М.П. Драгоманова

\section{ІННОВАТИКА ФОРМУВАННЯ СТРАТЕГІЇ БЕЗПЕКИ В КОНТЕКСТІ ПРОФЕСІЙНОї ПІДГОТОВКИ}

У статті обтрунтовано питання стратегії безпеки в контексті професійної підготовки та формування iї інновачійності. Здійснено аналіз законодавчих регламентів національної безпеки України, уточнено тлумачення основних категорій понятійно-категоріального апарату дослідження. Встановлено, щзо стратегію інновачійного розвитку визначають як інноваційний шлях перспектив нарощення інтелектуального потенціалу краӥни для досягнення мети інноваційного розвитку суспільства зі забезпеченням якості й безпеки життя на засадах сталості шляхом вирішення сучасних науково-технічних завдань при реалізації державноі інноваційної політики за умов модернізації сфери освіти, науки й інноватики.

Ключові слова: стратегія безпеки; інноватика; професійна підготовка; управління; тезаурус; регламент.

Jim. 16.

Oleksandr Slabetskiy, Postgraduate Student of the Adult Education Department, National Mykhaylo Drahomanov Pedagogical University

\section{AN INNOVATION OF FORMATION OF SAFETY STRATEGY IN THE CONTEXT OF PROFESSIONAL TRAINING}

The article substantiates the issues of security strategy in the context of professional training and the formation of its innovation. The analysis of legislative regulations of national security of Ukraine is carried out, the interpretation of the basic categories of the conceptual and categorical apparatus of research is specified. It is established that the priority definitions of "innovation development strategy" in scientific and legislative aspects are considered as an innovative mechanism for long-term development of the country's academic potential to achieve goals and objectives of innovation (in all spheres of social activity, quality and safety of life through sustainability); modernization of professional training of a new formation capable of satisfying the social order of the current stage of civilizational development in the context of global environmental challenges and dangers of violation of territorial integrity and state sovereignty of Ukraine), which consist in approving an innovative model of strategies -analytical support by solving modern scientific and technical innovation problems in the implementation of state innovation policy. It is determined that the concept of "national security strategy" is traditionally interpreted as a formalized definition of the official position of the state in legal documents based on the results of systematic analysis of quality and safety of society and the country at a particular stage of historical milestone. national interests and anticipation, elimination 